\title{
MEASURES WITH MULTIPLE PURPOSES: PUZZLES FROM EC—SEAL PRODUCTS
}

\author{
Donald H. Regan*
}

European Communities_-Measures Prohibiting the Importation and Marketing of Seal Products ${ }^{1}$ is the first case in which the dispute system of the World Trade Organization (WTO) has wrestled with a regulation that pursued multiple conflicting, legitimate purposes. (I will explain later why Brazil-Retreaded Tyres ${ }^{2}$ is not such a case.) This generates puzzles about applying the definition of a "technical regulation" to complex measures; about whether an exception to a ban can be justified by a purpose different from that of the ban; and about how to apply "less restrictive alternative" analysis to measures with multiple goals. The first of these puzzles is unique to the Agreement on Technical Barriers to Trade (TBT) ${ }^{3}$; the second and third concern the TBT, the General Agreement on Tariffs and Trade (GATT) ${ }^{4}$, and probably other agreements.

The European Union (EU) seal products regulation banned the local production, sale, or import of seal and seal products, on "public morals" grounds. The asserted purpose of the ban was to protect the moral sensibilities of European citizens who would be offended by the marketing in the EU of products from seals that were killed inhumanely. ${ }^{5}$ For convenience, I shall refer to this as the "seal welfare" purpose (even though it is formally about moral feelings, not actual seal welfare). There was an exception to the ban that allowed the marketing of seal products from seals killed by members of Inuit communities on traditional hunts. ${ }^{6}$ The purpose of this exception was to help preserve Inuit culture. The seal welfare purpose and the Inuit culture purpose are both genuine and legitimate purposes. But in the case of seal products from Inuit hunts, which involve some inhumane seal killing, the purposes conflict. The EU resolved the conflict in that case in favor of the Inuit, and against the seals. ${ }^{7}$

* William W. Bishop Jr. Collegiate Professor of Law at the University of Michigan Law School.

Originally published online 25 June 2015.

1 Appellate Body Report, European Communities-Measures Prohibiting the Importation and Marketing of Seal Products, WT/DS400/AB/R, WT/DS401/AB/R (Adopted June 18, 2014) [hereinafter Appellate Body Report, EC-Seal Products].

2 Appellate Body Report, Brazil-Measures Affecting Imports of Retreaded Tyres, WT/332/AB/R (Adopted Dec. 17, 2007).

${ }^{3}$ Agreement on Technical Barriers to Trade, Apr. 15, 1994, Marrakesh Agreement Establishing the World Trade Organization, Annex 1A, 1868 UNTS 120.

${ }^{4}$ General Agreement on Tariffs and Trade 1994, Apr. 15, 1994, Marrakesh Agreement Establishing the World Trade Organization, Annex 1A, 1867 UNTS 187.

${ }^{5}$ Regulation (EC) No 1007/2009 of the European Parliament and of the Council of 16 September 2009 on trade in seal products (Text with EEA relevance), 2009 O.J. (L 286) 36.

${ }^{6}$ Commission Regulation (EU) No 737/2010 of 10 August 2010 laying down detailed rules for the implementation of Regulation (EC) No 1007/2009 of the European Parliament and of the Council on trade in seal products (Text with EEA relevance), 2010 O.J. (L 216) 1.

${ }^{7}$ For discussion of a variety of important questions about this case that do not specially implicate multiple purposes, see Philip Levy \& Donald Regan, EC-Seal Products: Seals and Sensibilities (TBT Aspects of the Panel and Appellate Body Reports), 14 WORLD TRADE REV. 337 (2015). 


\section{Is the EU seal products regime a "technical regulation"?}

The EU seal products regime was challenged under both the TBT and the GATT. So the first issue under the TBT was whether the regime was a "technical regulation." The Panel said yes; the Appellate Body said no (or "not proved"). Neither tribunal produced a satisfactory analysis.

The Panel begins by citing the suggestion of the Appellate Body in EC-Asbestos 8 that a ban on asbestoscontaining products lays down a product characteristic and hence is a technical regulation, while a ban on natural asbestos does not lay down a product characteristic, since asbestos is a product. ${ }^{9}$ On this ground, the Panel suggests that the seals regime (the "measure") is a technical regulation insofar as it bans products that contain seal, but not insofar as it bans pure seal products. The Panel may suggest that the measure as a whole is a technical regulation because of its application to seal-containing products, but that is not clear. In any case, the Panel eventually finds another ground that clearly applies to the measure in both its aspects. In effect, the Panel finds that "having been killed by an Inuit" is a "product characteristic." So the Inuit exception, which applies to all sorts of seal products, lays down a product characteristic, and the whole measure is a technical regulation. This is unpersuasive. Aside from the fact that "having been killed by an Inuit" does not sound like anything we would normally regard as a "product characteristic", the Panel's approach would mean that every process and production method (PPM) lays down a product characteristic, which makes the reference to PPM's in the definition of technical regulations surplusage. ${ }^{10}$

The Appellate Body brusquely rejects the idea that "having been killed by an Inuit" is a product characteristic. ${ }^{11}$ It also accepts the EC-Asbestos-based distinction between pure seal products and seal-containing products. So it has now identified three features of the measure that bear on whether it is a technical regulation: (1) the fact that the measure generally bans seal-containing products counts in favor of its being a technical regulation; (2) the fact that the measure generally bans pure seal products counts against; and (3) the fact that the Inuit exception does not lay down a product characteristic counts against. What to do with these three propositions? The Appellate Body says repeatedly both that the decision whether the measure is a technical regulation must be made in respect of the measure as a whole, and that the tribunal must try to identify the essential feature of the measure. There is plainly some tension between these ideas. And the tension is reflected in a lack of clarity about how the Appellate Body finally decides the case. At some points, it seems to say that of the three listed features of the measure, two count against its being a technical regulation, and only one counts in favor, so the weight is against. Elsewhere the Appellate Body says that the seal regime "is not concerned with banning the placing on the EU market of seal products as such," but rather is concerned with regulating which hunters' seal products can come in, so the Inuit exception is the "main feature of the measure." And hence the measure is not a technical regulation. ${ }^{12}$

Both of the Appellate Body's analyses are unpersuasive. The "nose-counting over features" approach is too insensitive to how we individuate features, and it would break down if the EU had simply banned seal products with no exceptions (there would be one feature pointing in each direction). On the other hand, trying to identify the "main feature" of a complex measure is often senseless. In this case, the Appellate Body's claim that the

8 Appellate Body Report, European Communities-Measures Affecting Asbestos and Products Containing Asbestos, WT/DS235/AB/R (Adopted Apr. 5, 2001).

9 Panel Report, European Communities-Measures Prohibiting the Importation and Marketing of Seal Products, para. 7.104, W'T/DS400/R, WT/DS401/R (Adopted June 18, 2014).

10 Alexia Herwig makes the same point in Too much Zeal on Seals? Animal Welfare, Public Morals and Consumer Ethics at the Bar of the WTO, 15 World TRADE REV. 109 (2016).

${ }^{11}$ Appellate Body Report, EC-Seal Products, supra note 1, at para. 5.45.

${ }^{12} \underline{I d}$. at para. 5.58 . 
Inuit exception is the "main feature" of the measure is implausible. There would be no reason to have an Inuit exception if there were not a prior reason (seal welfare) to ban seal products; there would be no regulation at all. To my mind, the ban and the exception are equally essential aspects of the measure. But if anything is primary, it must be the ban. It is the ban that embodies the purpose that called the whole scheme into existence.

Whatever the shortcomings of the Appellate Body's analysis of this issue, I think the Appellate Body got the right result, and probably for the right underlying reasons. There is simply nothing "technical" about this measure, neither in the ban on seal products nor in the Inuit exception. We need an approach to deciding whether a measure is a "technical regulation" that reflects the presence of the word "technical" in that phrase, in the title of the Agreement, and in many dozens of provisions. Note also, the Preamble to the TBT mentions a goal of encouraging "transfer of technology." And as the Seal Products Appellate Body itself points out, TBT Article 2.9 presupposes that technical regulations have at least some "technical content."

Of course, the word "technical" is far from self-defining. But it is helpful to ask why we have a special agreement about "technical" barriers to trade at all. Article 2, which is the heart of the TBT, differs from the GATT in two ways: it applies to a narrower range of measures (only to "technical regulations"); and it applies additional disciplines (a free-standing "least restrictive alternative" requirement, and a conditional obligation to use international standards). These two divergences from the GATT ought to be connected. More specifically, the narrower range of application ought to explain the appropriateness of the additional disciplines. The natural suggestion is that, like the Agreement on Sanitary and Phytosanitary Measures $(\underline{\mathrm{SPS}})^{13}$, the TBT is about measures where established scientific methods can be brought to bear in reviewing regulatory choices (more so than with the general run of GATT measures). The availability of scientific methods both makes well-grounded international standards more likely, and makes the identification of equally effective less restrictive alternatives more reliable. But then, we must interpret "technical regulation" in such a way that established scientific methods are in fact distinctively relevant.

I have no space to develop this approach here, but it would require reconsidering our (still limited) jurisprudence about what is a technical regulation from the ground up. To give just one example, consider a hypothetical version of the EU seals regime. If the EU had thought that adequate monitoring was possible, it might have laid down precise requirements on how seals must be killed if their products are to be marketed in the EU. There might be rules on the distance from which seals could be shot; on the caliber and type of ammunition; on the maximum wind velocity and current when the shot is taken; on the design of the boats (to allow a steady shot); on the weight and design of clubs used for stunning seals; and so on. The effects of all of these standards might be tested by scientific studies. These rules about permissible seal hunting techniques (a perfectly natural word choice here) seem like good candidates for being a "technical regulation."

Notice that in reviewing this regime, there would be no reason at all to distinguish between its application to pure seal products and to seal-containing products. So to get the right result, we have to give up the Asbestos distinction. That distinction is suspect anyway. Absent evidence to the contrary, the reasons for excluding natural asbestos seem to be precisely as "technical" as the reasons for excluding asbestos-containing products. There is much work to be done to develop a jurisprudence along the lines I suggest. But we do not have a clear jurisprudence now on what is a "technical regulation". In the end, a sensibly grounded jurisprudence will be more predictable and will get better results. ${ }^{14}$

${ }^{13}$ Agreement on the Application of Sanitary and Phytosanitary Measures, Apr. 15, 1994, Marrakesh Agreement Establishing the World Trade Organization, Annex 1A, 1867 UNTS 493.

${ }^{14}$ Note in passing that the "technical content" approach could still allow us, without great strain, to regard all labeling rules as technical regulations, even if they are about "non-technical" aspects of the product. The label is an important aspect of a product as people consider purchasing it, and we can test the efficacy of various labels in communicating information. 
None of this final discussion on "technical content" addresses directly the problem of complex regulations. But it suggests that the right approach might be to say that a measure is a technical regulation if any significant aspect of it involves technical content, and then to apply the special disciplines of the TBT only to the measure's technical aspects.

\section{Must an exception to a ban be justified by the same purpose as the ban?}

Both the Panel and the Appellate Body in EC-Seal Products claim to find in Brazil-Tyres the rule that an exception to a ban cannot be justified by a different purpose than the ban. I shall refer to this as the "BrazilTyres pseudo-rule." "Pseudo-rule" for three reasons: First, it is a bad rule. Second, if the Brazil-Tyres Appellate Body actually meant to announce it, it was on the basis of a misreading of U.S.—Shrimp ${ }^{15}$. And third, even the Brazil_-Tyres Appellate Body does not seem wholeheartedly committed to the pseudo-rule.

The Panel in EC — Seal Products, having identified the Brazil-Tyres pseudo-rule, decides that it doesn't have to apply it to the present case. But as the Appellate Body points out, they don't give any very clear explanation of why not. The Appellate Body does not simply ignore the pseudo-rule; but what exactly they do with it is unclear. Lorand Bartels, who disapproves of the pseudo-rule (at least as a strict rule), argues that the Seal Products Appellate Body does not treat a violation of the pseudo-rule as in itself a violation of the GATT Article XX chapeau, but rather treats it as just one factor that counts against the legality of the regulation. ${ }^{16}$ I share Bartels's dislike of the pseudo-rule, but I am less sanguine than he is about the Appellate Body's position. The Appellate Body is unclear, but the frequency with which they mention the pseudo-rule, and the fact that they give it pride of place in their summary of why the regulation violates the chapeau, suggests that they at least give it substantial weight as evidence for a violation. ${ }^{17}$ In any event, we should not be satisfied just because the Appellate Body arguably does not treat a violation of the pseudo-rule as conclusive of illegality. They should give the pseudo-rule no weight at all.

Responsible regulation often involves taking account of different, and conflicting, purposes. That means making trade-offs, often by a regulation in the form of a ban with exceptions. And discrimination introduced by an exception is not rendered "arbitrary," or "unjustifiable," or a "disguised restriction" just because the purpose of the exception is different from the purpose of the ban. The only shadow of a reason for saying an exception cannot be justified by a different purpose from the ban is the suggestion that multiple purposes are evidence of disguised discrimination. In EC-Seal Products, for example, it could be suggested that the Inuit exception means the EU does not really care about seal welfare. But this is thoroughly implausible. There is completely persuasive evidence that the EU, like many other countries, cares about seal welfare. Indeed, on the facts of this case, there was no possible purpose for the ban other than protecting seals. The regulation could not have been primarily about advantaging the Greenland Inuit, because it apparently harmed even them, by making consumers more conscious of the harm to seals from all seal hunts. ${ }^{18}$

It might be said that in regulations with claimed multiple purposes, there are more opportunities for disguising discriminatory intent. That may be a reason for looking more carefully at the multiple purposes; but it is not in itself evidence that any claimed purpose is illegitimate. It is also true that the existence of the Inuit exception (for example) puts an upper bound on the strength of the European Union's commitment to seal welfare. But of course the location of that upper bound depends on the strength of the European Union's commitment to

${ }^{15}$ Appellate Body Report, United States_-Import Prohibition of Certain Shrimp and Shrimp Products, WT/DS58/AB/R (Adopted Nov. 6, 1998).

${ }^{16}$ Lorand Bartels, The Chapean of the General Exceptions in the WTO GATT and GATS Agreement, 109 AJIL 95 (2015).

${ }^{17}$ Appellate Body Report, EC-Seal Products, supra note 1, at para. 5.45.

18 See Kevin McGwin, EU ban blamed for rapid decline of Greenland sealing, ARCTIC J. (Mar. 14, 2014). 
preserving Inuit culture. And in any event, a possibly weaker commitment to seal welfare (entailed by the upper bound) is not the same as a disguised commitment to something else entirely. In sum, there is no ground for thinking that having a ban justified by one purpose and an exception justified by a different purpose should count substantively against a regulation at all. A prophylactic rule against multiple purposes might still make sense if innocent regulations with multiple purposes were rare. But in fact, they are the very stuff of law making.

Let us now consider the origins of the Brazil-Tyres pseudo-rule. The only justification the Brazil-Tyres Appellate Body suggests for the pseudo-rule is the following passage discussing U.S.—Shrimp ${ }^{19}$ :

We note, for example, that one of the bases on which the Appellate Body relied in U.S.—Shrimp for concluding that the operation of the measure at issue resulted in unjustifiable discrimination was that one particular aspect of the application of the measure (the measure implied that, in certain circumstances, shrimp caught abroad using methods identical to those employed in the United States would be excluded from the United States market) was 'difficult to reconcile with the declared objective of protecting and conserving sea turtles'. Accordingly, we have difficulty understanding how discrimination might be viewed as complying with the chapeau of Article XX when the alleged rationale for discriminating does not relate to the pursuit of or would go against the objective that was provisionally found to justify a measure under a paragraph of Article XX.20

But the final sentence here, taken at face value, is a non sequitur, a serious over-generalization from U.S.Shrimp. In U.S.—Shrimp, the United States did not offer any justification for its discrimination against certain shrimpers who used U.S.-style turtle excluding devices (TED) that was different from the underlying turtleprotection rationale of the regime. The United States did not assert multiple purposes. It asserted one and only one purpose, turtle-protection. And so, far from objecting to an exception based on a second purpose, the U.S.-Shrimp Appellate Body actually objected to the lack of an exception (for TED-users from non-certified countries) that was required by the United States' one purpose. In sum, there is no reason at all to think the U.S.-Shrimp Appellate Body meant to announce the Brazil-Tyres pseudo-rule.

Finally, as noted above, even the Brazil-Tyres Appellate Body does not seem wholeheartedly committed to the pseudo-rule. Notice first that they did not need the pseudo-rule to find Brazil in violation, because the purpose behind the Mercosur exception was illegitimate considered just in itself. It is doubtful whether Brazil actually had an obligation under Mercosur to admit retreaded tyres, except because of its own choice in the Mercosur litigation not to rely on Mercosur's Article XX equivalent. And in any event, a WTO respondent cannot avoid its WTO obligation just by pointing to a conflicting obligation imposed by a treaty to which the WTO complainant is not a party. (GATT Article XXIV specifically allows this in some cases, but the BrazilTyres Appellate Body explains why there is no Article XXIV defense in this case. ${ }^{21}$ ) The Appellate Body never says in so many words that the purpose behind the Mercosur exception is illegitimate. But they do develop the points I have just summarized, which are quite unnecessary for the application of the pseudo-rule. Which suggests they were reluctant to rely on the pseudo-rule by itself.

In the end, neither U.S._Shrimp nor Brazil-Tyres has any bearing at all on a case like EC-Seal Products. Neither U.S._Shrimp nor Brazil_-Tyres involved an exception based on a legitimate purpose.

19 Appellate Body Report, United States_-Import Prohibition of Certain Shrimp and Shrimp Products, supra note 15.

${ }^{20}$ Appellate Body Report, Brazil-Measures Affecting Imports of Retreaded Tyres, supra note 2, at para. 227, discussing Appellate Body Report, United States-Import Prohibition of Certain Shrimp and Shrimp Products, supra note 15, at para. 165 (citations omitted).

${ }^{21}$ Appellate Body Report, Brazil-Measures Affecting Imports of Retreaded Tyres, supra note 2, at para. 234, n.445. 


\section{How do we apply less restrictive alternative analysis to multiple purposes?}

Once we have established that regulations with multiple, conflicting purposes are permitted, the question arises how we apply less restrictive alternative analysis to such regulations. Both the Panel and Appellate Body conducted their explicit less restrictive alternative analysis only in terms of the seal welfare purpose. This did no harm in this case, but we will see that it could. We will also see that when the Panel and Appellate Body eventually found a violation in the disparate impact on Canadian Inuit and Greenland Inuit seal products, they implicitly engaged in a less restrictive alternative analysis that involved both the seal welfare and Inuit culture purposes.

Let us first see why a less restrictive alternative analysis that focuses only on one purpose can produce unacceptable results. In EC-Seal Products, if we ask simply whether the regulation is necessary for the protection of Inuit culture, the answer is clearly no. Repealing the regulation entirely would be less trade restrictive, and probably better for the Inuit. ${ }^{22}$ But plainly we should not require the EU to use this alternative, which leaves one of their legitimate goals, seal welfare, totally unprotected. If we ask instead whether the regulation is necessary for the seal welfare goal, it is not quite so obvious how we can get an unacceptable result. On the one hand, an alternative cannot logically be less restrictive of Greenland Inuit seal products, which are currently admitted. On the other hand, both Panel and Appellate Body regard it as established that any alternative that was less restrictive of other seal products (either commercial, or Canadian Inuit de facto) would achieve less seal welfare. So it appears that any less trade restrictive measure would reduce seal welfare. But this overlooks a possibility. Suppose that the Inuit hunt does more damage to seal welfare, per seal killed, than the commercial hunt. (The Panel discusses evidence that points both ways on this issue: commercial hunters may be under pressure to kill more seals faster; but Inuit hunters sometimes use nets.) For convenience, let us assign hypothetical numbers that almost certainly overstate any actual difference. Let us imagine that ten thousand dollars worth of Inuit seal products are accompanied by the inhumane killing of ten seals, whereas ten thousand dollars worth of commercial seal products are accompanied by the inhumane killing of only five seals. Now suppose we impose a quota on Inuit seal imports that reduces the value imported by five thousand dollars; and at the same time we open a quota for commercial seal imports totaling ten thousand dollars. The result will be five thousand dollars more trade overall, and the same total number of inhumanely killed seals (five fewer from the Inuit hunt, and five more from the commercial hunt). So this is a less restrictive alternative. But again it should be clear that requiring the EU to use this alternative would be unacceptable, because that would ignore the EU's desired level of achievement of the Inuit culture goal.

So we have to attend to both goals, and the question is, what do we mean by a "less restrictive alternative" when the regulation pursues multiple goals? It is a commonplace of existing less restrictive alternative doctrine that the regulating Member is entitled to achieve its own chosen level of protection. The phrase "own level of protection" seems to presuppose that the regulation has just one goal. But there is an obvious generalization of the "own level of protection" idea. When the regulation serves multiple, conflicting goals, which require trade-offs, then a less restrictive alternative must leave the regulator at least as well off as the actual measure, by reference to the regulator's own evaluation of the combined achievement of the various goals. To make the idea clearer, note that there is a standard realization of this idea, when the world is sufficiently well behaved, in terms of the regulator's indifference curves, which summarize the trade-offs between the goals that leave the regulator equally well off, at various levels of satisfaction. If the regulator's preferences can be represented by indifference curves, then we can say that an eligible "alternative" must leave the regulator on the same or a higher indifference curve.

22 See Kevin McGwin, supra note 18, and accompanying text. 
Of course, the regulator's preferences may not be representable by traditional indifference curves, if, for example, the goods (or the preferences) are "lumpy". And even if there are well-behaved indifference curves in principle, the reviewing tribunal will normally not be able to construct them in any detail from the very limited behavioral evidence it has of the regulator's preferences. But that impossibility does not give the tribunal warrant to evaluate the goals, or to make the trade-offs, for itself. So in practice, a less restrictive alternative will often have to be one that achieves at least as much of every goal as the actual measure. Still, what is required in principle is not that the alternative should achieve at least as much of every goal as the actual measure. What is required in principle is that the alternative should leave the regulator at least as well off as the actual measure, by the regulator's own lights, in view of the trade-offs it would make.

Once we have multiple goals, there is room for all sorts of interactions, and sometimes the structure of the regulatory problem will allow the tribunal to plausibly extrapolate the regulator's preferences and find a less restrictive alternative that achieves enough more of one regulatory goal to make up (by the regulator's own lights) for achieving less of some other. That seems to be what lies behind the holding in the present case that the EU did not treat Canadian Inuit and Greenland Inuit even-handedly. After all, there is a prima facie justification for the disparate impact on the two communities: because the Greenland Inuit have their own processing facility, and the Canadian Inuit rely on commercial processors, there is more risk of commercial seal products sneaking in under the Inuit umbrella with Canadian Inuit products than with Greenland Inuit products. That suggests that the finding of a violation must have a "less restrictive alternative" rationale. Now, the costs and benefits here have a quite distinctive structure. So far as the benefits to Inuit culture and the harm to Inuit-bunted seals are concerned, there is no difference between the Canadian Inuit and the Greenland Inuit. So if there were no danger of commercial seal products sneaking in, the EU's own evaluation, extrapolated from the treatment of Greenland Inuit seal products, would find a net benefit in admitting Canadian Inuit seal products (the additional benefit to Inuit culture would outweigh the additional loss in seal welfare). That means that an attestation program that admitted Canadian Inuit seal products would be a less restrictive alternative as long as it could hold the seal-welfare cost from commercial products that "sneak in" below that net benefit. To put it another way, the trade-off the EU has made in dealing with Greenland Inuit seal products (where commercial infiltration is not an issue) has the unobvious consequence that, when they consider Canadian Inuit products, the EU is not entitled to have a standard of "zero-risk of admitting disguised commercial seal products," which is what seems to have motivated their strict segregated-processing requirement. In effect, the tribunals seem to have relied on the view that the EU ought to be able to design an attestation program that keeps the commercial "leakage" low enough.

One final point. In a single sentence of EC-Seal Products, the Appellate Body suggests that the EU is required to guarantee that Inuit hunts are as humane as reasonably possible. ${ }^{23}$ This requirement flows naturally from the general theory of rationality that leads to the least restrictive alternative requirement; but it is not an application of the standard least restrictive alternative principle itself. The least restrictive alternative principle says that for any specified regulatory benefit, we must minimize the trade cost. But the principle the Appellate Body suggests here is that for any specified trade cost (since they are not proposing a way to reduce the trade cost), we must maximize the regulatory benefit. In this case, where there are multiple regulatory values, maximizing the regulatory benefit requires minimizing the cost to seal welfare of achieving any specified amount of Inuit culture preservation, which is what the Appellate Body calls for. There is an interesting question about how the litigation is supposed to proceed under the "maximize the benefit" principle. In traditional less restrictive alternative cases, the complainant country is expected to propose less trade-restrictive alternatives, and it has a clear incentive to do so. But where we are talking about maximizing the regulatory benefit from a given level

23 Appellate Body Report, EC—Seal Products, supra note 1, at para. 5.320. 
of trade restriction, the complainant country has no incentive to suggest alternative measures. Nor does the Appellate Body itself suggest any specific benefit-increasing measures at this point in EC-Seal Products. If the Appellate Body is asking the regulating country to justify its regulatory choice by "proving a negative" (the absence of any more beneficial measure), the Appellate Body should be deferential in review. 